\title{
Early Biochemical Indicators of Hypoxic-Ischemic Encephalopathy after Birth Asphyxia
}

\author{
NICOLE NAGDYMAN, WOLFGANG KÖMEN, HAE-KYUNG KO, CHRISTIAN MÜLLER, AND \\ MICHAEL OBLADEN \\ Department of Neonatology [N.N., W.K., H.-K.K., M.O.] and Institute of Laboratory Medicine [C.M.], \\ Charité University Hospital, Humboldt University Berlin, 13353 Berlin, Germany
}

\begin{abstract}
ABST
Hypoxic-ischemic encephalopathy (HIE) after perinatal as-
phyxia is a condition in which serum concentrations of brain-
specific biochemical markers may be elevated. Neuroprotective
interventions in asphyxiated newborns require early indicators of
brain damage to initiate therapy. We examined brain-specific
creatine kinase (CK-BB), protein $\mathrm{S}-100$, and neuron-specific
enolase in cord blood and $2,6,12$, and $24 \mathrm{~h}$ after birth in 29
asphyxiated and 20 control infants. At $2 \mathrm{~h}$ after birth, median
(quartiles) serum CK-BB concentration was $10.0 \mathrm{U} / \mathrm{L}(6.0-13.0$
$\mathrm{U} / \mathrm{L})$ in control infants, $16.0 \mathrm{U} / \mathrm{L}(13.0-23.5 \mathrm{U} / \mathrm{L})$ in infants with
no or mild HIE, and $46.5 \mathrm{U} / \mathrm{L}(21.4-83.0 \mathrm{U} / \mathrm{L})$ in infants with
moderate or severe HIE. Serum protein $\mathrm{S}-100$ was $1.6 \mu \mathrm{g} / \mathrm{L}$
(1.4-2.5 $\mu \mathrm{g} / \mathrm{L})$ in control infants, $2.9 \mu \mathrm{g} / \mathrm{L}(1.8-4.7 \mu \mathrm{g} / \mathrm{L})$ in
asphyxiated infants with no or mild HIE, and $17.0 \mu \mathrm{g} / \mathrm{L}(3.2-$
$34.1 \mu \mathrm{g} / \mathrm{L})$ in infants with moderate or severe $\mathrm{HIE} 2 \mathrm{~h}$ after birth.
No significant difference was detectable in serum neuron-specific
\end{abstract}
Perinatal asphyxia is a common cause of neonatal morbidity and mortality and neurologic disabilities among survivors. In addition to pulmonary, renal, and cardiac dysfunction, HIE develops in one third of asphyxiated newborns (1). Mild encephalopathy carries a good prognosis, although in moderate and severe encephalopathy the risk of death or neurologic sequelae increases greatly (2). Neuroprotective interventions are increasingly in the forefront of interest and have been shown to be effective in animal models. For clinical intervention, it is important to identify infants at a high risk for brain damage soon after birth and within the therapeutic window (3). Several indicators of brain damage have been investigated in the last decade (4-10). We examined the serum levels of three different brain proteins during the first day of life after birth asphyxia. Protein S-100 is a dimeric acidic calcium-binding protein constituting a major component of the cytosol of various cell types. Protein S-100B ( $\beta \beta$ subunits) and S-100A1 ( $\alpha \beta$ subunits) are predominantly present in astrocytes and

Received April 6, 2000; accepted October 17, 2000.

Correspondence and reprint requests: Nicole Nagdyman, M.D., Department of Neonatology, Charité University Hospital, Humboldt University Berlin, Augustenburger Platz 1, 13353 Berlin, Germany; e-mail: nicole.nagdyman@charite.de enolase between infants with no or mild and moderate or severe HIE 2 and $6 \mathrm{~h}$ after birth. A combination of serum protein S-100 (cutoff value, $8.5 \mu \mathrm{g} / \mathrm{L}$ ) and CK-BB (cutoff value, $18.8 \mathrm{U} / \mathrm{L}$ ) $2 \mathrm{~h}$ after birth had the highest predictive value (83\%) and specificity (95\%) of predicting moderate and severe HIE. Cord blood $\mathrm{pH}$ (cutoff value, <6.9) and cord blood base deficit (cutoff value, $>17 \mathrm{mM}$ ) increase the predictive values of protein S-100 and CK-BB. We conclude that elevated serum concentrations of protein S-100 and CK-BB reliably indicate moderate and severe HIE as early as 2 h after birth. (Pediatr Res 49: 502-506, 2001)
Abbreviations:
HIE, hypoxic, ischemic encephalopathy
NSE, neuron-specific enolase
CK-BB, brain-specific creatine kinase (E.C. 2.7.3.2)
aEEG, amplitude-integrated continuous EEG

Schwann cells (11). NSE is the neuronal form of the intracytoplasmic glycolytic enolase. It is found in neuronal cell bodies, axons, and neuroendocrine cells and in neuroendocrine tumors (12). CK-BB is found in both neurons and astrocytes. CK-BB and NSE levels have been found to be elevated after birth asphyxia, but few data exist that concern the early time course of these factors after the hypoxic-ischemic event (1317). Serum concentration of protein S-100 after birth asphyxia has not been assessed yet.

Our objectives were to investigate the postnatal time course of these markers in serum and to determine whether hypoxicischemic brain damage alters these markers and whether moderate or severe HIE can be predicted by elevated serum concentrations soon after birth.

\section{METHODS}

The study was performed from June 1998 to December 1999 and was approved by the Ethical Committee of the Medical Faculty, and written informed consent was given by the parents. We expected approximately one third of asphyxiated infants to exhibit moderate or severe HIE. Therefore, we decided to recruit approximately 30 infants in the asphyxia 
group and 20 control infants. The protocol included two study groups.

Asphyxia group. Twenty-nine subsequently full-term newborn infants (gestational age, 37-42 wk) who fulfilled the following criteria were included in the study: arterial blood cord $\mathrm{pH}$ value $<7.0$, or arterial blood cord $\mathrm{pH}$ value between 7.01 and 7.1 and also an Apgar score after 5 min of $<7$. The asphyxia group was subdivided according to the clinical examination: no or mild HIE with a good prognosis, and moderate or severe HIE with a greater risk of neural handicap (18).

Control group. Twenty full-term infants who fulfilled all the following criteria were enrolled in the study: no maternal illness, arterial blood cord $\mathrm{pH} \geq 7.2$, after $5 \mathrm{~min}$ an Apgar score of $>7$, and an uneventful course during the first $3 \mathrm{~d}$ of life. Predefined exclusion criteria for both groups were congenital anomalies, tumors, maternal drug addiction, severe infections, and congenital metabolic disorders, but no infant was excluded. Clinical data are given in Table 1.

Study design. Blood samples were collected from cord blood and 2, 6, 12, and $24 \mathrm{~h}$ after birth. Standardized neurologic examinations were performed at $6,12,24,48$, and $72 \mathrm{~h}$ of age. Mild HIE was assumed according to Sarnat and Sarnat (19) if hyperexcitability or hypotonia persisted without seizures for $\geq 72 \mathrm{~h}$ after birth; moderate if the newborn was lethargic, had hypotonia, weak primitive reflexes, and seizures; and severe if the infant had apnea, flaccid weakness, frequent seizures, or coma.

Analysis of CK-BB, protein S-100, and NSE. Creatine kinase was determined at $25^{\circ} \mathrm{C}$ according to the optimized German standard method on Dax 72 (Bayer, Munich, Germany) or Modular PP (Roche, Mannheim, Germany) random assessment clinical analyzers. To quantify CK-BB, creatine kinase isoenzymes were fractionated electrophoretically on agarose gels, visualized by in-gel substrate reaction for fluorometric scanning using Helena (Greiner, Flacht, Germany) gel kits and rapid electrophoresis system. The area under the CK-BB curve was used to calculate its concentration.

Protein S-100 was measured manually with a sandwich type immunoluminometric assay kit (Byk Sangtec, Dietzenbach, Germany) that used MAb and an LB952 luminometer
(Berthold, Wildbad, Germany). The assay uses three MAbs to detect the $\beta$ chains in the $\beta \beta$ (S-100B) and $\alpha \beta$ (S-100A1) dimers. We have used the term protein S-100 for simplicity, which refers to both of these dimers.

NSE was measured on a Cobas Core II immunoanalyzer with the NSE ELISA II kit (Roche), a one-step sandwich type enzyme immunoassay that used two specific mouse MAbs. Free $\mathrm{Hb}$, as an indicator of hemolysis, was quantified by bichromatic photometric measurement on Hitachi 911 or Modular PP analyzers (Roche). The manufacturer claims low detection limits of $0.1 \mu \mathrm{g} / \mathrm{L}$ for NSE and $0.02 \mu \mathrm{g} / \mathrm{L}$ for protein S-100. In 45 cases of low sample volumes, we reduced the amount of serum for protein S-100 assay from $100 \mu \mathrm{L}$ to 25 $\mu \mathrm{L}$, and $0.08 \mu \mathrm{g} / \mathrm{L}$ as the lower detection limit. Least square regression analysis for 18 samples were performed with both the original and the diluted protocol, and gave $y(25 \mu \mathrm{L})=$ $1.019 \times x(100 \mu \mathrm{L})-0.04$ with a regression coefficient of 0.98 . Time required for the measurement of $\mathrm{CK}-\mathrm{BB}$, protein S-100, and NSE was $0.5,3.5$, and $0.75 \mathrm{~h}$, respectively.

Data analysis. All values were presented as medians and interquartile ranges. Group comparisons were performed with the Mann-Whitney $U$ test. Positive predictive value, negative predictive value, sensitivity, and specificity for development of moderate or severe asphyxia were obtained using optimal cutoff levels and were calculated on the material used in our study. Receiver operating characteristic curves were assessed using the areas under the curves. Correlations were calculated by the Spearman rank method. For statistical analysis, the SPSS 5.02 for Windows (SPSS, Chicago, IL, U.S.A.) was used. Probability values $<0.05$ were considered to be significant.

\section{RESULTS}

Birth weight, gestational age, sex, and mode of delivery were similar among the control infants, infants with asphyxia without or with mild HIE, and asphyxiated newborns with moderate or severe HIE (Table 1). Of the 29 newborns with asphyxia, seven did not develop HIE but 22 did. Fifteen newborns had mild, four moderate, and three severe HIE. Both

Table 1. Characteristics of 29 infants with asphyxia and 20 control infants

\begin{tabular}{|c|c|c|c|c|}
\hline \multirow[b]{2}{*}{ Characteristics } & \multirow[b]{2}{*}{ Control group $n=20$} & \multicolumn{2}{|c|}{ Infants with asphyxia } & \multirow[b]{2}{*}{$p$ value } \\
\hline & & No or mild HIE $n=22$ & Moderate or severe HIE $n=7$ & \\
\hline Birth weight (g) & $3318(2962-3886)$ & $3540(3070-3800)$ & $3155(2625-3640)$ & NS* \\
\hline $\operatorname{Sex}(\mathbf{M} / F)$ & $6 / 14$ & $13 / 9$ & $2 / 5$ & NS* \\
\hline Mode of delivery & & & & NS* \\
\hline Cesarean section & 10 & 9 & 4 & \\
\hline Vaginal spontaneous & 6 & 8 & 2 & \\
\hline Inborns/outborns & $18 / 2$ & $15 / 7$ & $1 / 6$ & $0.026 \dagger$ \\
\hline Apgar score (1 min) & $8(7-9)$ & $4(2-7)$ & $2(1-2)$ & $0.01 \dagger$ \\
\hline Apgar score (5 min) & $9(8-10)$ & $6(5-8)$ & $5(3-5)$ & $0.03 \dagger$ \\
\hline Arterial cord blood $\mathbf{p H}$ & $7.25(7.22-7.28)$ & $6.98(6.87-7.01)$ & $6.75(6.62-6.90)$ & $0.008 \dagger$ \\
\hline Arterial cord blood base deficit & $5(3-6)$ & $13(11-16)$ & $22(17-28)$ & $0.03 \dagger$ \\
\hline
\end{tabular}

Results are presented as medium (quartiles).

$* p$ values are for comparison between control infants $(n=20)$ and infants with asphyxia $(n=29)$. $\dagger p$ values are for comparison between infants with no or mild HIE and moderate or severe HIE. 
groups with asphyxia differed in Apgar scores at 1 and 5 min, arterial blood cord $\mathrm{pH}$, and base deficit (Table 1). Two asphyxiated infants with severe HIE died; one within $12 \mathrm{~h}$ because of multiorgan failure, the other at d 26 with grade 4 intraventricular hemorrhage and renal and cardiac dysfunction. The third infant with severe HIE suffered from meconium aspiration and needed artificial respiration for $4 \mathrm{~d}$. No artificial respiration was necessary in the four infants with moderate HIE, but one of them had renal failure.

$\boldsymbol{C K}-\boldsymbol{B} \boldsymbol{B}$. At every time interval there was a significant difference $(p<0.05)$ in serum CK-BB concentrations between the asphyxia and the control groups (Table 2). Serum CK-BB was significantly higher in infants with moderate or severe HIE when compared with infants with no or mild HIE 2, 6, and $12 \mathrm{~h}$ after birth (Table 2). No difference was found between the two asphyxia groups in cord blood and $24 \mathrm{~h}$ after birth.

Protein S-100. At every time interval there was a significant difference $(p<0.05)$ in serum protein S-100 concentrations between the asphyxia group and the control group (Table 2). Serum protein S-100 was significantly higher in infants with moderate or severe HIE when compared with infants with no or mild HIE 2 and $6 \mathrm{~h}$ after birth (Table 2). No difference was observed between the two asphyxia groups at birth and 12 and $24 \mathrm{~h}$ after birth.

NSE. At any time interval we could not detect a significant difference in serum NSE concentrations between the control group and the asphyxiated infants (Table 2). However, serum NSE was higher in infants with moderate or severe HIE compared with infants with no or mild HIE 12 and $24 \mathrm{~h}$ after birth (Table 2). No difference was found between the two asphyxia groups at birth and 2 and $6 \mathrm{~h}$ after birth. Blood hemolysis increased the serum NSE levels, but no significant difference in hemolysis was detectable in the different groups.

The predictive capacities for serum CK-BB, protein S-100, NSE, $\mathrm{pH}$, base deficit, and Apgar score (at $1 \mathrm{~min}$ ) for HIE of moderate or severe degree are shown in Table 3. Combinations of biochemical measurements and combinations of biochemical markers with cord blood $\mathrm{pH}$, cord blood base deficit, and Apgar score at $1 \mathrm{~min}$ are given in Table 4. The combination of serum protein S-100 (cutoff value, $8.5 \mu \mathrm{g} / \mathrm{L}$ ) and CK-BB (cutoff value, $18.8 \mathrm{U} / \mathrm{L}$ ) at $2 \mathrm{~h}$ had the highest positive predictive value and specificity (Table 4 ) for biochemical markers. A combination of serum protein S-100 at $2 \mathrm{~h}$ after birth with cord blood $\mathrm{pH}$ (cutoff value, <6.9) or cord blood base deficit (cutoff value, $>17 \mathrm{mM} / \mathrm{L}$ ) increased the positive predictive value and specificity. Correlation between the serum concentrations of protein S-100 and CK-BB at $2 \mathrm{~h}$ are given in Figure $1\left(\rho_{\mathrm{s}}=\right.$ $0.66 ; p<0.001)$.

\section{DISCUSSION}

In adults, neuronal necrosis and apoptosis after global ischemia are slow, and last for several hours to several days (20). Studies in perinatal animals suggest a quicker cellular destruction (3). It is not known how long the window of opportunity remains open for intervention, but any intervention will be more successful early after the insult (21). Energy substrates in the neonatal brain continue to run down for 12 to $48 \mathrm{~h}$ after hypoxia (22). Therefore an intervention might be effective 2 to $6 \mathrm{~h}$ after birth asphyxia. As neuroprotective interventions may be harmful (23), it is important to find early and reliable indicators of brain damage or of poor long-term prognosis to initiate or end neuroprotective treatment. Cranial tomography, somatosensory evoked potentials, and magnetic resonance tomography are useful for prognosis, but not in the first $24 \mathrm{~h}$ after birth $(24,25)$. Magnetic resonance spectroscopy reveals brain energy compromise (6), but is not practicable in most clinical situations. aEEG is a useful diagnostic tool for assessing encephalopathy. Previous reports $(4,5)$ established a high predictive value of postnatal aEEG for neurologic outcome.

Several studies measured biochemical factors in serum and cerebrospinal fluid glial fibrillary acidic protein after $12-48 \mathrm{~h}$

Table 2. Serum concentrations of $C K-B B$, protein S-100, and NSE at different times after asphyxia

\begin{tabular}{|c|c|c|c|c|c|}
\hline \multirow{2}{*}{$\begin{array}{l}\text { Biochemical markers } \\
\text { (median/interquartiles) }\end{array}$} & \multirow[b]{2}{*}{ Control group } & \multicolumn{2}{|c|}{ Infants with asphyxia } & \multirow[b]{2}{*}{$p$ value* } & \multirow[b]{2}{*}{$p$ value } \\
\hline & & No or mild HIE & Moderate or severe HIE & & \\
\hline \multicolumn{6}{|l|}{ CK-BB (U/L) } \\
\hline $2 \mathrm{~h}$ & $10.0(6.0-13.0)$ & $16.0(13.0-23.5)$ & $46.5(21.4-83.0)$ & $<0.0001$ & 0.003 \\
\hline $6 \mathrm{~h}$ & $7.0(4.3-8.8)$ & $10.4(6.0-16.0)$ & $27.0(18.0-55.0)$ & 0.002 & 0.002 \\
\hline $12 \mathrm{~h}$ & $5.0(4.0-6.8)$ & $12.5(6.0-15.6)$ & $33.3(18.1-52.0)$ & $<0.0001$ & 0.012 \\
\hline $24 \mathrm{~h}$ & $5.0(3.0-6.8)$ & $6.5(4.0-14.0)$ & $9.5(7.0-17.5)$ & 0.028 & NS \\
\hline Cord blood & $0.8(0.7-1.0)$ & $1.5(1.1-1.9)$ & $2.5(1.5-3.7)$ & $<0.0001$ & NS \\
\hline $2 \mathrm{~h}$ & $1.6(1.4-2.5)$ & $2.9(1.8-4.7)$ & $17.0(3.2-34.1)$ & $<0.0001$ & 0.008 \\
\hline $6 \mathrm{~h}$ & $1.5(1.2-2.3)$ & $2.5(1.6-3.8)$ & $27.6(2.6-52.3)$ & 0.001 & 0.015 \\
\hline $12 \mathrm{~h}$ & $1.2(1.1-1.5)$ & $1.8(1.5-2.3)$ & $3.1(1.3-23.1)$ & 0.001 & NS \\
\hline $24 \mathrm{~h}$ & $1.0(0.9-1.4)$ & $1.6(1.0-2.6)$ & $3.9(1.2-9.0)$ & 0.04 & NS \\
\hline \multicolumn{6}{|l|}{ NSE $(\mu \mathrm{g} / \mathrm{L})$} \\
\hline Cord blood & $29.6(17.8-55.9)$ & $48.9(20.1-74.7)$ & $106.8(60.5-108.1)$ & NS & NS \\
\hline
\end{tabular}

$* p$ values are for comparison between all asphyxiated infants and controls. $\dagger p$ values are for comparison between asphyxiated infants with no or mild HIE and infants with moderate or severe HIE. 
Table 3. Values for predicting moderate or severe HIE

\begin{tabular}{|c|c|c|c|c|c|c|}
\hline Variable & Cutoff value & PPV (\%) & NPV $(\%)$ & Sens $(\%)$ & Spec $(\%)$ & AUC \\
\hline \multicolumn{7}{|l|}{ Protein S-100 } \\
\hline $2 \mathrm{~h}$ & $8.5 \mu \mathrm{g} / \mathrm{L}$ & 71 & 90 & 71 & 90 & 0.832 \\
\hline $6 \mathrm{~h}$ & $4.6 \mu \mathrm{g} / \mathrm{L}$ & 63 & 90 & 71 & 86 & 0.805 \\
\hline $2 \mathrm{~h}$ & $18.8 \mathrm{U} / \mathrm{L}$ & 46 & 100 & 100 & 65 & 0.879 \\
\hline $6 \mathrm{~h}$ & $17.0 \mathrm{U} / \mathrm{L}$ & 55 & 94 & 86 & 77 & 0.877 \\
\hline \multicolumn{7}{|l|}{ NSE } \\
\hline Arterial cord blood $\mathrm{pH}$ & $<6.9$ & 46 & 89 & 71 & 73 & 0.838 \\
\hline Cord blood base deficit & $>17 \mathrm{mM} / \mathrm{L}$ & 50 & 94 & 83 & 77 & 0.905 \\
\hline Apgar score (1 min) & $<3$ & 50 & 94 & 73 & 86 & 0.825 \\
\hline
\end{tabular}

Abbreviations: PPV, positive predictive value; NPV, negative predictive value; Sens, sensitivity, Spec, specificity; AUC, area under the curve. It is important that markers demonstrate high specificity and high positive predictive value.

Table 4. Combination of factors for predicting moderate or severe HIE

\begin{tabular}{|c|c|c|c|c|}
\hline Variable & PPV (\%) & NPV (\%) & Sens $(\%)$ & Spec $(\%)$ \\
\hline Protein S-100 and CK-BB & 83 & 91 & 71 & 95 \\
\hline CK-BB and cord blood $\mathrm{pH}$ & 71 & 91 & 71 & 91 \\
\hline CK-BB and cord blood base deficit & 67 & 91 & 67 & 91 \\
\hline Protein S-100 and cord blood $\mathrm{pH}$ & 100 & 88 & 57 & 100 \\
\hline Protein S-100 and cord blood base deficit & 100 & 92 & 67 & 100 \\
\hline Protein S-100 and Apgar score (1 min) & 80 & 88 & 57 & 96 \\
\hline
\end{tabular}

Abbreviations: PPV, positive predictive value; NPV, negative predictive value; Sens, sensitivity; Spec, specificity. Values of serum factors are at $2 \mathrm{~h}$ after birth. Cutoff values are given in Table 3.

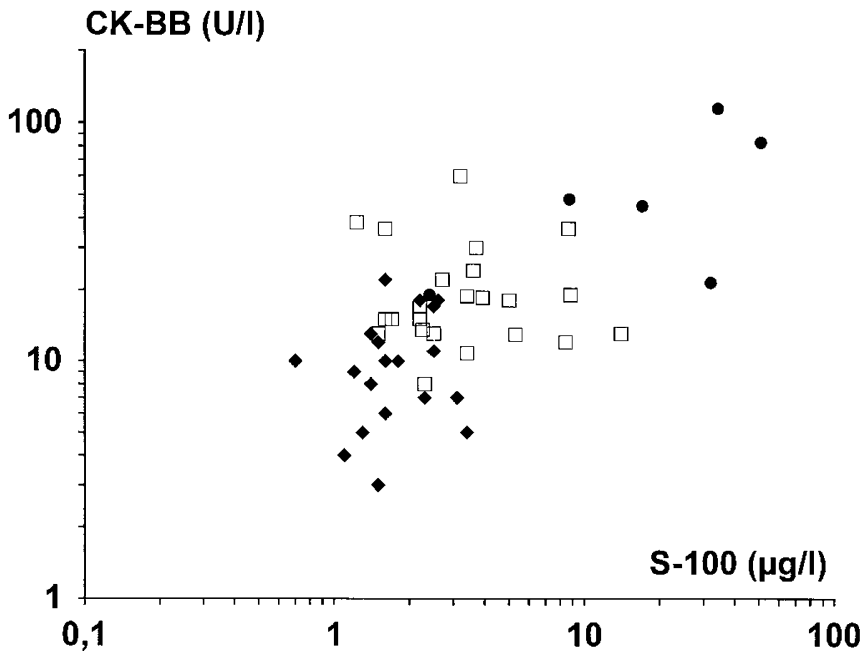

Fig. 1. Correlation of serum CK-BB and protein S-100 in 45 infants at an age of $2 \mathrm{~h}$. Measurements for control infants $(\bullet)$, asphyxiated infants with no or mild HIE ( $\square$ ), and asphyxiated infants with moderate or severe HIE (๑) are shown.

(7); excitatory amino acids after 18-66 h (8); and IL-6 $12 \mathrm{~h}$ after the hypoxic-ischemic event (9). Urinary lactate:creatine ratio predicts HIE within $6 \mathrm{~h}$ with ${ }^{1} \mathrm{H}$ nuclear magnetic resonance spectroscopy (10), but a useful indicator for HIE should be specific even earlier, and requires a rapid and readily available laboratory technique. Besides this, infants with asphyxia often have oliguria, and urine sampling may not be possible (26). Our results do not confirm serum NSE as an early predictor of HIE. As late as $12 \mathrm{~h}$ after birth, serum concentrations of NSE increased significantly in the infants with moderate and severe HIE when compared with infants with no or mild HIE. Results of other studies $(16,17)$ with serum NSE in asphyxiated newborns are in concordance with our data, whereas NSE in cerebrospinal fluid seems to be more favorable.

Concerning CK-BB, these results are in accordance with studies where the increase was within the first 4-15 h of life (13-15). Our serum CK-BB activities were lower than in the studies of Walsh et al. (14) and Fernandez et al. (15), which was probably related to the measurement of total creatine kinase activity at different temperatures. CK-BB is also expressed in placenta, lungs, gastrointestinal tract, and kidneys, all of which might be involved in the sequelae of asphyxia. Although the placenta is rich in CK-BB activity, it seems that its contribution to serum CK-BB levels in the neonate is negligible (27). Cuestas (13) found that the blood CK-BB levels were not increased in neonates with renal or gastrointestinal tract disorders. Therefore, we assume that the increased levels originate mainly from the brain of the asphyxiated infants.

Protein S-100 is also known to be present in the striated muscle, heart, kidneys, adipocytes, and thymus of newborns $(28,29)$. Until now, no study has examined the serum values of protein S-100 in asphyxiated and age-related control infants. In adults, protein S-100 is not detectable in serum under normal conditions (30); however, in cerebral diseases it ranged from zero (31) to highly predictive values (32). Additionally, clinical studies in adults evaluated different time patterns for the increase of serum protein S-100, such as transient increase after cardiac operations (33), peak level within $24 \mathrm{~h}$ after cerebral hemorrhage (34) or global cerebral ischemia (32), and a peak level at $\mathrm{d} 3$ after an acute ischemic stroke $(34,35)$. In the serum of infants, protein S-100 has been determined after cardiac 
operations and extracorporeal circulation, demonstrating agerelated concentrations that were highest in neonates and infants with Down's syndrome with a pattern of transient increase similar to adult patients (36). In asphyxia, serum protein S-100 release follows a pattern similar to the transient increase observed after cardiac operations. We postulate that in case of asphyxia, elevated levels in serum are caused by leakage of protein S-100 into the extracellular fluid after hypoxic damage of glial cell and neuronal membranes and by lower renal excretion. The integrity of the blood-brain barrier seems to influence its levels in serum, which explains why serum protein S-100 concentration is lower in adults than in infants (36). Recent studies detected transient serum elevations of protein S-100 without any relationship to permanent neuronal damage, and the question has arisen as to whether protein S-100 arises from noncerebral sources $(37,38)$.

We could not exclude the possibility that protein S-100 and CK-BB release comes only from the brain. In regard to this, it might be a simple epiphenomenon of general ischemia related to asphyxia. Asphyxia may involve the whole body, and the release of proteins into the blood might be a general sign of change in cell membrane integrity and vascular permeability caused by the whole body ischemic-reperfusion injury. In our opinion, no single diagnostic marker should form the basis for decisions on neuroprotective therapy. But the decision as to which infants could be candidates for postasphyxial treatment should probably be based on several findings, which include aEEG, cord blood $\mathrm{pH}$, cord blood base deficit, Apgar score, and serum protein S-100 and CK-BB. These biochemical markers may be helpful in deciding whether an early initiated neuroprotective therapy should be continued or stopped. However, our data, obtained from a small number of infants, refer to HIE and not permanent brain damage. Neurodevelopment follow-up studies in our infants in the next few years will show whether elevated serum protein S-100 and CK-BB will also predict developmental delay.

\section{REFERENCES}

1. Goodwin TM, Belai I, Hernandez P, Durand M, Paul RH 1992 Asphyxial complications in the term newborn with severe umbilical acidemia. Am J Obstet Gynecol 167:1506-1512

2. Finer NN, Robertson CM, Richards RT, Pinnel LE, Peters KL 1981 Hypoxicischemic encephalopathy in term neonates: perinatal factors and outcome. J Pediat 98:112-117

3. Vannucci RC, Perlman JM 1997 Interventions for perinatal hypoxic-ischemic encephalopathy. Pediatrics 100:1004-1014

4. Hellström-Westas L, Rosén I, Svenningsen NW 1995 Predictive value of early continuous amplitude integrated EEG recordings on outcome after severe birth asphyxia in full term infants. Arch Dis Child 72:F34-F38

5. Al Naqeeb N, Edwards AD, Cowan FM, Azzopardi D 1999 Assessment of neonatal encephalopathy by amplitude-integrated electroencephalography. Pediatrics 103:1263-1271

6. Thoresen M, Penrice J, Lorek A, Cady EB, Wylezinska M, Kirkbride V, Cooper CE, Brown GC, Edwards AD, Wyatt JS, Reynolds EOR 1995 Mild hypothermia after severe transient hypoxia-ischemia ameliorates delayed cerebral energy failure in newborn piglets. Pediatr Res 37:667-670

7. Blennow M, Hagberg H, Rosengren L 1995 Glial fibrillary acidic protein in the cerebrospinal fluid: a possible indicator of prognosis in full-term asphyxiated newborn infants? Pediatr Res 37:260-264

8. Hagberg H, Thornberg E, Blennow M, Kjellmer I, Lagercrantz H, Thiringer K, Hamberger A, Sandberg M 1993 Excitatory amino acids in the cerebrospinal fluid of asphyxiated infants: relationship to hypoxic-ischemic encephalopathy. Acta Paediatr 82:925-929

9. Martin-Ancel A, Garcia-Alix A, Pascual-Salcedo D, Cabanas F, Valcarce M, Quero J 1997 Interleukin-6 in the cerebrospinal fluid after perinatal asphyxia is related to early and late neurological manifestations. Pediatrics 100:789-794
10. Huang CC, Wang ST, Chang YC, Lin KP, Wu PL 1999 Measurement of the urinary lactate: creatinine ratio for the early identification of newborn infants at risk for hypoxic-ischemic encephalopathy. N Engl J Med 341:328-335

11. Kligman D, Hilt DC 1988 The protein S 100 family. Trends Biochem Sci 13:437-443

12. Rider CC, Taylor CB 1975 Evidence for a new form of enolase in rat brain. Biochem Biophy Res Commun 66:814-820

13. Cuestas RA 1980 Creatine kinase isoenzymes in high risk infants. Pediatr Res 14:935-938

14. Walsh P, Jedeikin R, Ellis G, Primhak R, Maleka SK 1982 Assessment of neurologic outcome in asphyxiated term infants by use of serial CK-BB isoenzyme measurement. J Pediatr 101:988-992

15. Fernandez F, Verdu A, Quero J, Perez-Higueras A 1987 Serum CKP-BB isoenzyme in the assessment of brain damage in asphyxiated term infants. Acta Pediatr Scand 76:914-918

16. Garcia-Alix A, Cabanas F, Pellicer A, Hernanz A, Stiris TA, Quero J 1994 Neuronspecific enolase and myelin basic protein: relationship of cerebrospinal fluid concentrations to the neurologic condition of asphyxiated full-term infants. Pediatrics 93:234-240

17. Thornberg E, Thiringer K, Hagberg H, Kjellmer I 1995 Neuron specific enolase in asphyxiated newborns: association with encephalopathy and cerebral function monitor trace. Arch Dis Child Fetal Neonatal Ed 72:F39-F42

18. Levene MI, Sands C, Grindulis H, Moore JR 1986 Comparison of two methods of predicting outcome in perinatal asphyxia. Lancet 1:67-69

19. Sarnat HB, Sarnat MS 1976 Neonatal encephalopathy following fetal distress: a clinical and electroencephalographic study. Arch Neurol 33:696-705

20. Horn M, Schlote W 1992 Delayed neuronal death and delayed neuronal recovery in the human brain following global ischemia. Acta Neuropathol 85:79-87

21. Levene MI, Evans DJ, Mason S, Brown J 1999 An international network for evaluating neuroprotective therapy after severe birth asphyxia. Semin Perinatol 23:226-233

22. Lorek A, Takei Y, Cady EB, Wyatt JS, Penrice J, Edwards AD, Peebles D, Wylezinska M, Owen-Reece H, Kirkbride V, Cooper CE, Aldridge RF, Roth SC, Brown G, Delpy DT, Reynolds EOR 1994 Delayed ("secondary") cerebral energy failure after acute hypoxia-ischemia in the newborn piglet: continuous 48-hour studies by phosphorus magnetic resonance spectroscopy. Pediatr Res 36:699-706

23. Levene M, Gibson N, Fenton A, Papathoma E, Barnett D 1990 The use of calcium-channel blocker, nicardipine, for severely asphyxiated newborn infants. Dev Med Child Neurol 32:567-574

24. de Vries LS, Pierrat V, Eken P, Minami T, Daniels H, Casaer P 1991 Prognostic value of early somatosensory evoked potentials for adverse outcome in full-term infants with birth asphyxia. Brain Dev 13:320-325

25. Fitzhardinge PM, Flodmark O, Fitz CR, Ashby S 1981 The prognostic value of computed tomography as an adjunct to assessment of the term infants with postasphyxial encephalopathy. J Pediatr 99:777-781

26. Perlman JM, Tack ED 1988 Renal injury in asphyxiated newborn infant: relation to neurologic outcome. J Pediatr 113:875-879

27. Laboda HM, Britton VJ 1977 Creatine kinase isoenzyme activity in human placenta and in serum of women in labour. Clin Chem 23:1329-1335

28. Suzuki F, Kato K 1986 Induction of adipose S-100 protein release by free fatty acids in adipocytes. Biochim Biophys Acta 889:84-90

29. Kojima K, Wekerle H, Lassmann H, Berger T, Linington C 1997 Induction of experimental autoimmune encephalitis by CD $4+\mathrm{T}$ cells specific for an astrocyte protein, S100 beta. J Neural Transm Suppl 49:43-51

30. Fassbender K, Schmidt R, Schreiner A, Fatar M, Mühlhauser F, Daffertshofer M, Hennerici M 1997 Leakage of brain-originated proteins in peripheral blood: temporal profile and diagnostic value in early ischemic stroke. J Neurol Sci 148:101-105

31. Büttner T, Lack B, Jäger M, Wünsche W, Kuhn W, Müller T, Przuntek H, Postert T 1999 Serum levels of neuron-specific enolase and protein S-100 after single tonicclonic seizures. J Neurol 246:459-461

32. Martens P, Raabe A, Johnsson P 1998 Serum S-100 and neuron-specific enolase for prediction of regaining consciousness after global cerebral ischemia. Stroke 29:23632366

33. Westaby S, Johnsson P, Parry AJ, Blomquist S, Solem JO, Alling C, Pillai R, Taggert DP, Grebenik C, Stahl E 1996 Serum S100 protein: a potential marker for cerebral events during cardiopulmonary bypass. Ann Thorac Surg 61:88-92

34. Kim JS, Yoon SS, Kim YH, Ryu JS 1996 Serial measurement of interleukin-6, transforming growth factor- $\beta$, and S-100 protein in patients with acute stroke. Stroke 27:1553-1557

35. Missler U, Wiesmann M, Friedrich C, Kaps M 1997 S-100 protein and neuronspecific enolase concentrations in blood as indicators of infarction volume and prognosis in acute ischemic stroke. Stroke 28:1956-1960

36. Lindberg L, Olsson AK, Anderson K, Jögi P 1998 Serum S-100 protein levels after pediatric cardiac operations: a possible new marker for postperfusion cerebral injury. J Thorac Cardiovasc Surg 116:281-285

37. Jönsson H, Blomquist S, Alling C, Johnsson P 1998 Early release of S100 after cardiac surgery: interference from extracerebral sources. Ann Thorac Surg 66:1493 (abstr)

38. Westaby S, Saatvedt K, White S, Katsumata T, Oeveren W, Bhatnagar NK, Brown S, Halligan PW 2000 Is there a relationship between serum S-100 $\beta$ and neuropsychologic dysfunction after cardiopulmonary bypass? J Thorac Cardiovasc Surg 119:132137 